\title{
Factors Influencing the Purchase of Agricultural Tractors: An Empirical Study
}

\author{
${ }^{1}$ Dr. V. Sivakumar, ${ }^{2}$ Dr. S. Kaliyamoorthy, \\ ${ }^{1}$ Assistant Professor Alagappa Institute of Management Alagappa University KARAIKUDI \\ Tamilnadu, INDIA \\ ${ }^{2}$ Professor \& Director Alagappa Institute of Management Alagappa University KARAIKUDI \\ Tamilnadu, INDIA
}

\begin{abstract}
Consumers make purchase decisions in each and every aspect of their life. Thus studying consumer behaviour becomes more vital. All marketing decisions \& activities are based on assumptions about consumer behavior. The following objectives were framed for the paper, to study the factors influencing the purchase of agricultural tractors and to evaluate the most important factors like brand name, subsidy, horsepower, maintenance etc considered for the purchase of agricultural tractors. The study was carried out in Sivaganga district of Tamilnadu state. Descriptive research design has been used in this study. The researcher has used both primary and secondary data for this research. The researcher has collected primary data from the tractor owners who had bought their tractor for service to the dealer point during the study period in sivaganga district. Factor analysis was used to find out the most influencing factors considered by the respondents while making the purchase decision of tractor. It is found as per the ranking given by the respondents subsidy is ranked first and followed by sources consulted, horse power, after sales service, price and brand name respectively are considered for purchase of tractors.
\end{abstract}

Key Words: Agricultural Equipments, Tractors, Consumer Behavior, Factor Analysis, Branding, Marketing and Production of Equipments etc.

\section{Introduction About The Study:}

Consumers make purchase decisions in each and every aspect of their life. Thus studying consumer behaviour becomes more vital. All marketing decisions \& activities are based on assumptions about consumer behavior. Consumer behaviour deals with the behaviour that consumer displays in the consumption of goods right from purchasing, using, evaluating \& disposing them. In other way, it deals with what they buy, how often they use it when they by it, why they buy it where they buy and how they evaluate it after purchase. Understanding the consumer purchase process is critical to a marketer so as to design the marketing activities effectively.

Each step in the consumer decision making process is highly influenced by both internal and external factors. The internal factors include the individual's own motivation personality, perception, learning attitude and his own past experience in addition to the internal influencing factors, the external factors like the company's marketing efforts, ideas/opinions of friends, relations, family members and reference group members also have profound impact on the purchase decision of individuals.

\section{Consumer Behaviour}

The study of consumer is the study of how individuals make decisions to spend their available resources (time, money, effort) on consumption - related items. It includes the study of what they buy, why they buy it, when they buy it, where they buy it and how often they use it, how they evaluate after the purchase and the impact of such evaluations on future purchases and how they dispose of it. Consumer behaviour is concerned with the study of factors that influence people's behaviour in a buying situation. Marketers can make better marketing decisions only when they know why and how individuals make their consumption decisions.

\section{Buying Decision Process}

Consumers engage in a decision process to deal with the marketing environment and make purchases. The consumer goes through a series of logical stages to arrive at a decision when he faces a problem that could be resolved through a purchase. A typical buying process consists of the following five stages:

\section{Problem Recognition}

The buying process starts where the buyer recognizes a problem or need. The need may be triggered by internal or external stimuli. Marketers need to identify the circumstances that trigger a particular need. 


\section{Information Search}

An aroused consumer will be inclined to search for more information. Consumer information sources fall into four groups: Personal Sources: Family, friends, neighbours, acquaintances. Commercial Sources: Advertising, salespersons, dealers, packaging, displays. Public Sources: Mass media, Consumer -rating organization. Experimental Sources: Handling, Examining, using the product.

\section{Evaluation Of Alternatives} situations.

There is no single evaluation process used by all consumers or by one consumer in all buying

\section{Purchase Decision}

In executing a purchase intention, the consumer may make up to five purchase sub decisions: a brand decision, vendor decision, quantity decision, timing decision and payment method decision.

\section{Post Purchase Behaviour}

After purchasing the product the consumer will experience some level of satisfaction or dissatisfaction. The marketer's job does not end when the product is bought. Marketers must monitor post purchase satisfaction, post purchase actions and post purchase product uses too.

The above said consumer decision making process is influenced by many factors like personal, psychological, social, economic and marketing factors.

\section{Objectives Of The Study}

The following objectives were framed for the paper:

$\checkmark$ To study the factors influencing the purchase of agricultural tractors.

$\checkmark$ To evaluate the most important factors like brand name, subsidy, horsepower, maintenance etc considered for the purchase of agricultural tractors.

\section{Limitations Of The Study}

Like any other social research, this research also has the following inherent limitations:

1. This study is restricted to Sivaganga district only.

2. This study is confined only to the agricultural tractor owners alone. They may not be generalized to other type of tractor consumers.

\section{Research Design}

\section{Research Methodology}

Descriptive research design has been used in this study. The objective of a descriptive study is to answer the 'who, what, where and how' of the subject under investigation.

\section{Type Of Data Collected}

The researcher has used both primary and secondary data for his research. primary data from the tractor owners who had brought their tractor for service to the dealer point during the study period in Sivaganga district.

\section{Methods Of Data Collection}

For the descriptive type of researches, the best - suited research approach is survey method. The researcher has used interview schedule for the purpose of collecting primary data from the farm tractor owners for the study.

\section{Sampling Unit}

The researcher has chosen the tractor consumers belonging to sivaganga district as the sample unit.

\section{Sample Size}

The sample size for the study is determined as 90 .

\section{Sample Methodology:}

The sampling method used by the researcher in this study is non-probability sampling and the method used is convenient sampling method. This method has been chosen because the respondents belong to farming community and they should be willing to spend sometime to collect data. 
XVII. Analysis And Interpretation

Table - 1 Ranking of factors considered for buying tractor by the respondents

\begin{tabular}{|l|l|l|l|l|l|l|l|l|l|l|}
\hline Factor & $\mathbf{1}$ & $\mathbf{2}$ & $\mathbf{3}$ & $\mathbf{4}$ & $\mathbf{5}$ & $\mathbf{6}$ & $\mathbf{7}$ & $\begin{array}{l}\text { Total } \\
\text { source }\end{array}$ & Avg Source & Rank \\
\hline Price & 09 & 19 & 21 & 08 & 04 & - & 29 & 335 & 3.95 & 7 \\
\hline Subsidy & 53 & 24 & 12 & 1 & - & - & - & 576 & 6.4 & 1 \\
\hline Brand Name & 37 & 31 & 17 & 5 & - & - & - & 550 & 6.11 & 2 \\
\hline HP & 29 & 41 & 15 & 5 & - & - & - & 549 & 6.10 & 3 \\
\hline Maintenance & 21 & 20 & 36 & 5 & 4 & 3 & 1 & 486 & 5.4 & 4 \\
\hline ASS & 13 & 19 & 23 & 31 & 3 & 1 & - & 455 & 5.05 & 5 \\
\hline RSV & 07 & 11 & 16 & 21 & 33 & 2 & - & 382 & 4.24 & 6 \\
\hline
\end{tabular}

Source : Primary Data

\section{Interpretation}

From the above table it is very clear that subsidy factor is ranked as first in influencing the purchase of tractor, followed by brand name, horsepower of tractor, Maintenance, after sales service, resale value and price respectively.

\section{Factor Analysis}

The objective of factor analysis is to summarise a large number of variables into a small number of synthetic variable. Extraction method used is principal computer analysis, rotation method varimax with karsir normalization and rotation concluded in 14 iterations. The following is the table showing the variables and their description.

Table 2.1 variables and their description

\begin{tabular}{|l|l|l|}
\hline Variable & Communality & Description of variables \\
\hline VAR 00001 & 0.8824 & Availability of spares \\
\hline VAR 00002 & 0.7715 & Easy reparability \\
\hline VAR 00003 & 0.7849 & Mechanics reputation \\
\hline VAR 00004 & 0.6450 & Brand's reputation \\
\hline VAR 00005 & 0.7056 & Engine \\
\hline VAR 00006 & 0.6084 & Dealer's reputation \\
\hline VAR 00007 & 0.6910 & Look of the tractor \\
\hline VAR 00008 & 0.5243 & References by friends \\
\hline VAR 00009 & 0.4811 & Performance with regard to agricultural operations \\
\hline VAR 00010 & 0.6351 & Braking system \\
\hline VAR 00011 & 0.6230 & promotional offers \\
\hline VAR 00012 & 0.7737 & Horse power \\
\hline VAR 00013 & 0.6624 & Resale value \\
\hline VAR 00014 & 0.5581 & Cost of spares \\
\hline VAR 00015 & 0.6761 & Loan availability \\
\hline VAR 00016 & 0.6857 & Service backing \\
\hline VAR 00017 & 0.7235 & Mileage \\
\hline VAR 00018 & 0.2480 & Enhanced features. \\
\hline
\end{tabular}

\subsection{Variables and their factor loading's}

\begin{tabular}{|l|l|l|l|l|l|l|}
\hline Variable & Factor 1 & Factor 2 & Factor 3 & Factor 4 & Factor 5 & Communality \\
\hline VAR 00001 & -0.0466 & 0.9070 & -0.0338 & 0.2130 & 0.1050 & 0.8824 \\
\hline VAR 00002 & 0.0980 & 0.8500 & 0.0328 & -0.0189 & 0.1950 & 0.7715 \\
\hline VAR 00003 & 0.1040 & 0.1890 & -0.0494 & 0.1880 & 0.8370 & 0.7849 \\
\hline VAR 00004 & 0.1670 & -0.0200 & -0.0775 & 0.7380 & 0.2570 & 0.6450 \\
\hline VAR 00005 & 0.6030 & 0.5550 & 0.0672 & -0.0471 & -0.1650 & 0.7056 \\
\hline VAR 00006 & 0.0549 & 0.2050 & 0.1650 & 0.7310 & 0.0416 & 0.6084 \\
\hline VAR 00007 & 0.6950 & 0.2650 & 0.1100 & -0.1270 & 0.3310 & 0.6910 \\
\hline VAR 00008 & -0.0837 & 0.3570 & 0.2390 & 0.2770 & 0.5060 & 0.5243 \\
\hline VAR 00009 & 0.4750 & -0.1480 & 0.1830 & -0.0343 & 0.4460 & 0.4811 \\
\hline VAR 00010 & 0.7040 & 0.0045 & 0.2560 & 0.1650 & 0.2160 & 0.6351 \\
\hline VAR 00011 & -0.0661 & -0.0036 & 0.5860 & 0.5240 & 0.0249 & 0.2310 \\
\hline VAR 00012 & 0.7970 & -0.0784 & 0.0817 & 0.2690 & -0.2310 & 0.7737 \\
\hline VAR 00013 & 0.1740 & 0.1250 & 0.7750 & 0.0161 & 0.1250 & 0.6624 \\
\hline VAR 00014 & 0.2680 & -0.0282 & 0.6680 & -0.1970 & 0.0216 & 0.5581 \\
\hline VAR 00015 & 0.0856 & -0.0443 & 0.7270 & 0.3710 & -0.0247 & 0.6761 \\
\hline VAR 00016 & 0.4340 & 0.6400 & 0.2560 & 0.1160 & 0.0935 & 0.6857 \\
\hline VAR 00017 & 0.5020 & -0.4320 & -0.2190 & 0.2730 & 0.4030 & 0.7235 \\
\hline VAR 00018 & 0.3480 & -0.0615 & 0.0512 & 0.1600 & $: 0.3080$ & 0.2480 \\
\hline Eigen Value & 2.9388 & 2.7754 & 2.2522 & 1.9207 & 1.7924 & \\
\hline
\end{tabular}


Factor grouping and their description

\begin{tabular}{|l|l|}
\hline V5 & Engine \\
\hline V7 & Look of the tractor \\
\hline V9 & Performance with regard to agricultural operations \\
\hline V10 & Braking system \\
\hline V12 & Horse power \\
\hline V17 & Mileage \\
\hline V18 & Enhanced features \\
\hline
\end{tabular}

Factor 2 - Spares and Service

\begin{tabular}{|l|l|}
\hline V1 & Availability of Spares \\
\hline V2 & Easy reparability \\
\hline V16 & Service backing \\
\hline
\end{tabular}

Factor 3 - Economy

\begin{tabular}{|l|l|}
\hline V 11 & Promotional offers \\
\hline V 13 & Resale value \\
\hline V 14 & Cost of Spares \\
\hline V 15 & Loan availability \\
\hline
\end{tabular}

Factor 4 - Reputation

\begin{tabular}{|l|l|}
\hline V 4 & Brand's reputation \\
\hline V 6 & Dealer's reputation \\
\hline
\end{tabular}

Factor 5 - Reference group influence

\begin{tabular}{|l|l|}
\hline V 3 & Mechanic's advice \\
\hline V 8 & References by friends \\
\hline
\end{tabular}

Hence the above mentioned factors are the most influencing factors which make the consumer to prefer buying a tractor

\section{Friedman Test}

Friedman test is used for identifying whether there is any significant difference in the ranks given by respondents about various factors considered for buying tractor.

Ho: There exists no significant difference in the ranks given for various factors considered for buying tractors

Table 3

\begin{tabular}{|l|l|l|}
\hline \multicolumn{1}{|c|}{ Factors considered for buying tractor } & Mean Rank & Assignrd value \\
\hline Price & 4.83 & 5 \\
Subsidy & 1.19 & 1 \\
Brand Name & 5.55 & 7 \\
Horse Power & 3.52 & 3 \\
Maintenance & 5.18 & 6 \\
After sales service & 4.68 & 4 \\
Sources consulted before buying tractor & 3.04 & 2 \\
N & 90 & \\
Chi-Square & 277.542 & \\
df & 6 & \\
Asymp. Sig. P Value & .000 & \\
& P <0 .05 Significant & \\
\hline
\end{tabular}

Source: Primary Data

Inference It is found from the above table as per the ranking given by the respondents subsidy is ranked first and followed by sources consulted, horse power, after sales service, price and brand name respectively. According to the Friedman test results, the respondents ranking with regard to the factors considered for purchase of tractors are significantly different at 5 percent level of significance. 


\section{Findings From Factor Analysis:}

Factor analysis was used to find out the most influencing factors considered by the respondents while making the purchase decision of tractor. The researcher has grouped the factors into various heading as mentioned below.

- Factor 1

Factor 1 is titled on "product" consisting of variables like engine, look of the tractor, performance with regard to agricultural operation, Braking system, horse power, mileage and enhanced features.

- Factor 2

Factor is clubbed under the title "spare and services" which includes availability of spares, easy reparability and service backing.

- Factor 3

Factor 3 is titled an "Economy" and consists of promotional offers, resale value, cost of spares, loan availability.

- $\quad$ Factor 4

Factor 4 consists of brand's reputation and dealer reputation and it has been titled as "Reputation".

- Factor 5

Factor 5 is titled as reference group influence and consists of variables like mechanics advice and references by friends.

Hence these are the factors considered mainly by the consumers while making purchase of Agricultural Tractors in sivaganga district.

\section{Findings From Friedman Test:}

- It is found as per the ranking given by the respondents subsidy is ranked first and followed by sources consulted, horse power, after sales service, price and brand name respectively are considered for purchase of tractors. According to the Friedman test results, the respondents ranking with regard to the factors considered for purchase of tractors are significantly different at 5 percent level of significance.

\section{Conclusion}

The research work has given lot of inputs to the researcher with regard to consumer behaviour and the various factors which influence their purchase decision. The researcher has tried his level best to describe the facts that are prevailing in the market. The research output may help the manufacturer, and dealers of tractors an insight about the consumer's perception and it will further help them in promoting their product in a more effective way.

\section{References}

[1] Assael, Henry (1987), Consumer Behavior and Marketing Action, Kent Publishing Co.: Beston, p 87

[2] Kassarjian, Herald H., and Waltraub M. Kassarajan (1979), "Attitudes under low commitment, conditions", in: Attitude Research Plays for Higher Stakes, John C. Mahoney and Bernard Silverman (eds), American Marketing Association: Chicago.

[3] Petty, Richard E. and John T. Cacioppo (1986), C'omrnunication and Persuasion, Springer-Verlag: New York.

[4] Laurent, Gilles and Jean-Noel Kapferer (1985), "Measuring Consumer Involvement Profiles", Journal of Marketing Research, Vol.22 (February), pp 41-53

[5] Lilien, Gary L., Philip Kotler and Sridhar Moorthy, K. (1999), Marketing Models, Prentice Hall of India Pvt. Ltd.: New Delhi, pp 68-107.

[6] Kotler, Philip and Murali K. Mantrala (1985), "Flawed Products: Consumer Responses and Marketing Strategies", Journal of Consumer Marketing, (Summer), pp27-36.

[7] Dhanna, Mukesh (1984), "An Analysis of Consumer Behavior: A case Study of soft drinks in India”, Journal of Marketing, 16(7) March, pp 26-28.

[8] Stanton, William J, Micheal J. Etzel and Bruce J. Walker (1994), Fundamentals of Marketing, j0tti ed., McGraw Hill Inc.: Singapore, pp 129-136

[9] Kotler, Philip (2003), Marketing Management, 12th ed., Pearson Education Asia: Singapore, pp 287-291

[10] Schiffman, Leon G. and Leslie Lazer Kanuk (2004), Consumer Behaviour, 8th ed., Prentice Hall of India Pvt. Ltd.: New Delhi, p 8 . 